\author{
Andrzej Stasiak \\ University of Łódź \\ Institute of Urban Geography and Tourism Studies \\ Department of Leisure and Qualified Tourism \\ andrzej.stasiak@geo.uni.lodz.pl
}

\title{
GASTRONOMY AS A TOURISM ATTRACTION FOR ŁÓDŹ
}

\begin{abstract}
Over the last 25 years, a rapid development in gastronomic services in Łódź and other large Polish cities has been observed, as a result of a growing interest in good cooking both on the part of inhabitants and visitors (culinary tourism). The article is an attempt to describe the potential of gastronomic resources in Łódź as a possible basis for creating a new tourism product for the city. The paper presents a historical outline of Łódź gastronomy, the specificity of the local cuisine and its delicacies, the major culinary events, and the structure and location of gastronomic establishments at the beginning of the $21^{\text {st }} \mathrm{c}$., as well as other elements which may be used to create an attractive offer for tourists.
\end{abstract}

Keywords: gastronomy, culinary tourism, gastronomic tourism product, Łódź.

\section{INTRODUCTION}

The beginning of the $21^{\text {st }} \mathrm{c}$. was a time when Poles started to take an increasing interest in the problems of nutrition and cooking, as well as travelling in search of 'new tastes'. Culinary tourism is considered to be one of the more interesting and important trends in contemporary cultural tourism (DEREK 2013a, KRAKOWIAK \& STASIAK 2015). Travel of this type is inspired not only by consumption of dishes and drinks, but also by the tourists' interest in various aspects of food. As a rule, such journeys bring unique experiences and emotions: tourists meet famous chefs, take part in culinary events, workshops and cooking competitions ${ }^{1}$. Even if gastronomy is not the main purpose of their journey, good (original, traditional, famous) food, available at the place where they are staying, often tips the scales when it comes to the choice of holiday destination (STASIAK 2007).

The culinary offer plays an important role in the perception of the tourism attractiveness of a given city or region. That is why local gastronomy is increasingly being taken into account in tourism development strategies, becoming a component of the tourism product and an important element of promotion. The attractiveness of the gastronomic offer may result from original, long culinary traditions, the diversity of food products and services offered, and current gastronomic trends. These may be real or putative (KOWALCZYK 2014).
The main aim of the article is an analysis of the gastronomic services in Łódź in terms of the possibility of using them to create an original tourism product for the city. The author presents a history of Łódź gastronomy, describes local cuisine and its delicacies, the gastronomic resources of Łódź at the beginning of the $21^{\text {st }} \mathrm{c}$., as well as the most important culinary events and other elements of gastronomic potential.

\section{AN OUTLINE HISTORY OF ŁÓDŹ GASTRONOMY}

Describing the origins of Łódź gastronomy is problematic mainly due a lack of source materials. There are few works devoted to the history of gastronomy on Polish lands, and almost none as regards the history of Łódź gastronomy (JASKULSKI 2012). The earliest references to the gastronomic facilities in the area of contemporary Łódź come from the times before the city was granted municipal rights. Documents regarding the settlement based on German law include information about the possibility of running inns by heads of villages and urban citizens, as well as required payments. Despite gaining municipal rights (1423), forms of gastronomic activity remained 
very simple for several centuries. The first reliable data on the number of inns in agricultural Łódź comes from 1534. Six existed then in the centre and on the outskirts e.g. at the border between Łódź and the village of Bałuty (KLIMA \& BRATKOWSKI 2005).

The situation changed in the first half of the $19^{\text {th }} \mathrm{c}$., when the 'factory settlement' started to develop at an extraordinary pace. As a result, trade and services, including gastronomic, developed alongside. Initially, the most significant number were establishments selling alcohol: inns, taverns, beer cellars and bars. The first inn was built in the Nowy Miasto (New Town) market square in 1823. In 1827, other establishments of this type were opened in the Łódka settlement area (45 and 98 Piotrkowska St) and in the same year, a Łódź brewery was begun (NALEWAJKO 2006). The number of bars was growing fast, reaching 80-90 in the 1840s on the main streets (e.g. on Piotrkowska St), in the market places of the Old and New Towns, and near churches and factories. They were owned not only by craftsmen but also by Łódź industrialists e.g. Ludwik Geyer (KLIMA \& BRATKOWSKI 2005). The income from this activity was an important contribution to the city budget: in 1827 , it was about $75 \%$, and in the 1850s and 1860s, when the number of inns had fallen to 55, about 35\% (SUŁKOWSKA 2013). These establishments were the core of the so-called 'hospitality industry' (Polish traktiernia, German traktieren - to treat, host somebody) including cafés, pastry shops, tea houses and dairies which did not sell alcohol.

With time, differences in the standard of differing gastronomic establishments became obvious. Apart from traditional workers' taverns - beer cellars, traktiernias, bars and cafés for the middle class appeared, as well as luxurious restaurants for the élite (industrial bourgeoisie, merchants, representatives of free professions, top officials). The restaurants were divided into three categories, depending on the standard of amenity, quality of service, culinary offer and customer affluence (JASKULSKI 2012). The new establishments in Łódź were modelled mainly on western examples (French, Italian, English or German). It is interesting, however, that a permanent fixture was the samovar - a typically Russian device used for making tea.

The frequently changing owners, activity profiles and names, as well as the recurrent rebuilding and reorganising of the interiors, were reasons why we do not know much about the majority of Łódź gastronomic establishments. Some of them, however, left a permanent mark on the history of the city, like the Adamowski inn, tavern and garden (Parady $\dot{z}$ at 175a Piotrkowska Street), the Gehlig Brothers' Leśniczówka and garden, and two restaurants in Helenowski Park. Other frequently visited places were pastry shops: Szwetysz (on plac Wolności) and Aleksander Roszkowski's Roszek's (on the corner of Piotr- kowska and Moniuszki Sts) (JASKULSKI 2012). The most elegant before the First World War were hotel restaurants, e.g. in the Niemiecki, the Manteuffel, the Grand, the Savoy or the Polonia Palace (MILEWSKA \& WŁODARCZYK 2004).

After 1918, the number of gastronomic establishments started to grow again, due to the incorporation of the district of Bałuty with its population of 100000 into the city, as well as an inflow from the countryside, which led to the appearance of cheap restaurants and food outlets. In the 1920s, there were 300 (NALEWAJKO 2006). Particularly popular were those which served meals during the day and provided entertainment in the evenings (KRZYWIK KAŹMIERCZYK 2010). Among the most prestigious in Łódź was a restaurant in the newly opened (1918) Klukas Hotel (MILEWSKA \& WŁODARCZYK 2004).

During the Second World War, Germans took over all the best gastronomic establishments. Poles ate in small food outlets set up in flats, shops or warehouses by representatives of the intelligentsia, e.g. actors or teachers, who had lost their livelihood (KLIMA \& BRATKOWSKI 2005).

System changes after 1945 soon affected the gastronomic sector. Many private establishments were closed down, others were nationalized. A characteristic feature of that period was the appearance and development of so-called nationalized gastronomy, including staff canteens and 'milk bars'. In the 1950s, they made up nearly $50 \%$ of all catering establishments. In the 1970s, the number of state establishments gradually started to decrease (SUŁKOWSKA 2013), but the majority were still situated in the Old Town area and near Piotrkowska St (PIETRUSZKA 2015).

In the socialist period, several establishments in Łódź played a significant role in the social, cultural and even political life, and their fame travelled far beyond the city limits:

- Dworcowa restaurant in Łódź Fabryczna Station - one of the very few places open 24 hours a day; its customers were both travellers and local inhabitants;

- Turystyczna restaurant (22 Sienkiewicza St) a simple eatery, popular among manual workers and artists;

- Honoratka café (2 Moniuszki St) - a private establishment run between 1948-74 by Stefania Bruździńska; popular among artists (film makers in particular) as well as intellectual and academic élites; regular customers included J. Hoffman, R. Polański, D. Olbrychski and Z. Cybulski;

- Siódemki (77 Piotrkowska St) - a student's club, founded in 1960, where M. Urbaniak started his jazz career, and R. Polański often told jokes;

- Balaton - the first self-service bar and café (1960); 
- Malinowa and Złota restaurants and a café at the most prestigious Łódź hotel - the Grand (72 Piotrkowska St);

- Hortex Café (110 Piotrkowska St) - in the 1980s was famous for the best desserts in town.

\section{LOCAL DELICACIES - REGIONAL CUISINE}

The unique history of Łódź has left a mark on its culinary heritage. In the $19^{\text {th }} \mathrm{c}$., the city was gaining new inhabitants extremely rapidly ${ }^{2}$. The population was composed of various ethnic and religious groups including Poles, Germans, Jews and, to a lesser extent, Russians. It is not surprising then that the eating traditions and the delicacies of Polish, German, Jewish and Russian cuisines (in different variations) appeared. Ethnic variety overlapped with socio-economic diversity - simple workers had completely different eating habits to representatives of the industrial bourgeoisie. What was served on the table depended not only on ethnic origins or religion, but on economic status.

The meals eaten in workers' homes were simple, one-pot, filling dishes. As women worked in factories in the shift system and did not have time to cook, the meals were easy to prepare and could be reheated many times. Popular dishes were soups: flaki (tripe soup), cabbage soup, zalewajka (sour rye soup), pea soup, beetroot soup and black cherry soup. Their simplicity and cheapness were reflected in their colloquial names (fifka or dziad) (WOJCIECHOWSKA 2014). The main course consisted of meat (usually of poor quality, or offal) and with garnished potatoes or kasha. The meat was often pork lungs ( $d u d k i)$ served with potatoes and butter, as well as potato 'noodles' (prażoki) garnished with pork fat and cabbage. A popular dish was herring sold at street markets, especially that between the Old and New Town (this area is unofficial still named Herring Park).

The eating habits of the richest industrialists were totally different. Their tables were full of expensive, exquisite dishes, often imported from abroad or remote parts of the Russian Empire. The symbols of that luxury were champagne, 'Petersburg bliny and Astrakhan caviar' (JASKULSKI 2012).

Individual ethnic communities living in compact groups upheld their culinary traditions and eating habits. Unfortunately, as a result of the events that took place in the first half of the $20^{\text {th }} \mathrm{c}$. (the departure of Tsar's officials after 1918, the holocaust, the escape or relocation of Germans after the Second World War), the multiculturality of Łódź ended forever. Though the influences of other cuisines are still visible today, it is only a distant memory of the gastronomic wealth of former times. The relics of ethnic cuisines include: chatka (a sweet roll) and carp in the Jewish style, zulik (sweet bread with raisins), Russian lepioszki and German potato soup (WOJCIECHOWSKA 2014, ZARĘBSKA \& BOROWSKA 2015).

Lying at the intersection of historical regions (Mazovia, Wielkopolska, Silesia and Małopolska) the Łódź region has not developed its own, distinct cuisine but borrowed from its neighbours. That is why Łódź cuisine is a conglomerate of various dishes brought by settlers from different parts of Poland. Even prażoki, defined as typical of the Łódź region, are also known in Świętokrzyskie.

The impoverishment of the local cuisine and disappearance of culinary traditions were also the result of socialist times. The authorities' attempts to unify the country and eradicate regional differences, popularizing simplistic, socialist customs, standardizing the norms of food production, and finally the long economic crisis and shortages of basic products led to a decline in gastronomy. That period is commonly associated with vegetable salads with mayonnaise, herring, or jellied pig's feet (zimne nóżki/drygle), which were popular snacks when drinking vodka ${ }^{3}$ (KRZYWIK KAŹMIERCZYK 2014), liver sausage (lebera) and potato pancakes with sugar and cream.

The historical events mentioned above were the reason why currently Łódź does not have its own, commonly recognizable culinary delicacies. The list of traditional products compiled by the Ministry of Agriculture and Rural Development includes 85 from Łódź Province (województwo) out of 1483 from the whole country, but none from Łódź itself 4 .

In recent years, the media have announced competitions for dishes from Łódź. The most famous are knedle with strawberries (or plums) served with spring cabbage and pork chops. This dinner offered by the U Szwajcara restaurant won the 'Tastes of Łódz' competition in 2002. It was not the ingredients that were unusual, but their composition on one plate, based on Łódź tradition. In another competition for the best confectionery, the first prize was won by P. Skórka with a layer cake whose decoration represented plac Wolności. The menus of Łodź restaurants more and more often contain dishes whose names refer to the four cultures, as well as Ziemia Obiecana (The Promised Land) - a novel by Władysław Reymont and film by Andrzej Wajda. An inspiration for cooks is the film heritage of Łodz - the main idea of the $10^{\text {th }}$ Festiwal Dobrego Smaku ('Good Taste' Festival) in 2013 was 'culinarily stoked' (kulinarnie nakręceni - nakręceni having a double meaning either 'filmed' or 'stoked, very excited'). In 2015, to commemorate the Oscar for the best non-English film, the Wasiakowie pastry shop 
introduced cakes called Ida. However, these are all only single attempts to revive forgotten Łódź traditions or add local flavour to contemporary cooking.

\section{GASTRONOMIC FACILITIES IN $21^{\text {ST }}$ C. ŁÓDŹ}

The system transformation in Poland, which took place in the early 1990s, brought a decline in the textile industry, a dramatic increase in unemployment and the appearance of poverty enclaves in the city centre. Piotrkowska St also went downhill, with its few restaurants and one 'milk bar'. Despite the protests of the opposition, the President of Łódź, Grzegorz Palka, decided that the representative street of the city must be thoroughly renovated. The street surface and the lighting were changed, some tenement houses were refurbished and shops were privatized. Due to these investments, Piotrkowska returned to life: it started to have shopping, recreation and entertainment functions again; about 280 new shops were opened, including many exclusive brands. In addition, numerous new gastronomic establishments were set up and the Piotrkowska St Foundation organized large events, during which Guinness records in the tug of war or rolling the barrel were broken, a long, sandy beach was laid, a pyramid of ice was built in the middle of summer, and a gigantic spider's web was made from string (CUDNY 2002).

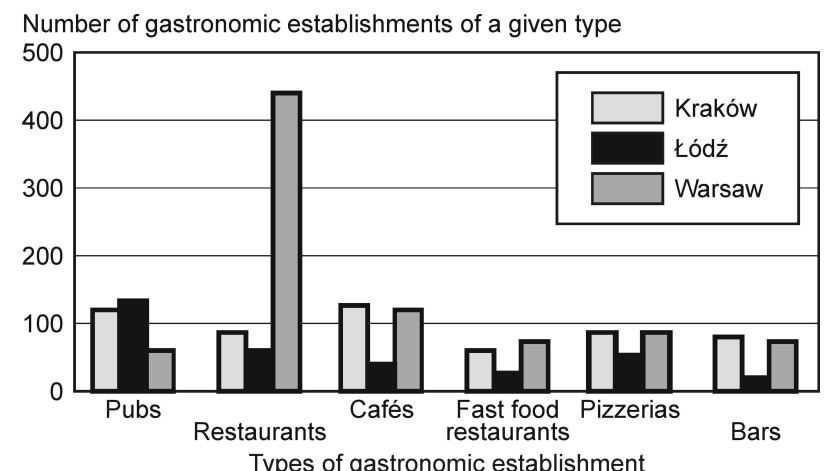

Fig. 1. Types of gastronomic establishment in Kraków, Łódź and Warsaw Source: M. MILEWSKA (2003)

The turn of the $21^{\text {st }} \mathrm{c}$. was the best time in the history of Łodź gastronomy. New pubs, cafés and restaurants were springing up in the city centre. A new phenomenon was outside terraces ('gardens'), differing in décor and the range of dishes served. They quickly gained popularity, both among Łódź inhabitants and visitors (CUDNY 2002). Another novelty was fast food (opening in hypermarkets too) as well as gastronomic outlets specializing in Asian cuisine (NALEWAJKO
2006). Piotrkowska St became the centre of night life, and Łódź started to be called the Polish capital of pubs. Colloquial language gained a new word - 'pubbing' - to describe a night-long pub spree.

A pub was 'a gastronomic establishment with limited choice of food services, a wide range of culturalentertainment services, offering at least 30 seats at tables and five at the bar, having a characteristic décor and atmosphere, playing a specific type of music, and organizing accompanying events' (MILEWSKA 2003, p. 81). In 2002, there were 132 establishments in Łódź understood in this way - more than in Kraków or Warsaw (Fig. 1). There were 5958 residents per pub, which was 4.4 times more than in Warsaw but slightly less than in Kraków. The ratio of the number of pubs per $\mathrm{km}^{2}$ was similar (Łódź - 0.45, Kraków - 0.38, Warsaw - 0.13) (MILEWSKA 2003).

Łódź stood out from other Polish cities not only because of the number of pubs, but also the high quality of their offer and their huge diversity. Generally, they were divided into classic, modelled on 'English' pubs (Rolling Stone, Piotrkowska 97, Irish Pub), and original ones which differed in décor, atmosphere, type of music and accompanying events. They included pubs with artistic atmosphere (Łódź Kaliska), industrial (Fabryka), ethnic, student, travel-related, under-ground, etc. At weekends, they organized concerts presenting all music styles, dances, fashion shows, special offers, fancy dress parties, dancing competitions and many other unusual events.

Łódź pubs were very densely distributed (Fig. 2). A large majority functioned in the city centre (Śródmieście) on Piotrkowska St where you could find one third of all pubs, and a further $19 \%$ were located in the streets crossing or adjacent to it. Student campuses had $11 \%$ of all pubs. Such a distribution confirmed the cultural-entertainment character of the city centre (MILEWSKA 2003).

Attractive décor, unique ambience and a very rich cultural and entertainment offer made pubs the most important Łódź tourism attraction at the beginning of the $21^{\text {st }}$ c. Such was the opinion of $78 \%$ out of 1264 respondents who took part in the survey conducted by M. MILEWSKA (2003), nearly 90\% had been approached in Łódź pubs (mainly in Łódź Kaliska, Fabryka, Jama Madejowa, West Side and Siódemki). The main motivations included the atmosphere $(90 \%)$, the fact that they were places for meeting friends (88\%), dancing $(77 \%)$ and arts events (60\%). The largest group consisted of Łódź inhabitants, but a relatively large number came from nearby powiats: Zgierz, Brzeziny, Łódź East, Pabianice and Skierniewice (over 50\%). There were some from Warsaw and Radom (over 30), as well as Wrocław, Kielce, Kraków and Upper Silesia (MILEWSKA 2003).

In the following years, the popularity of pubs started to decrease, on the other hand, the demand for 


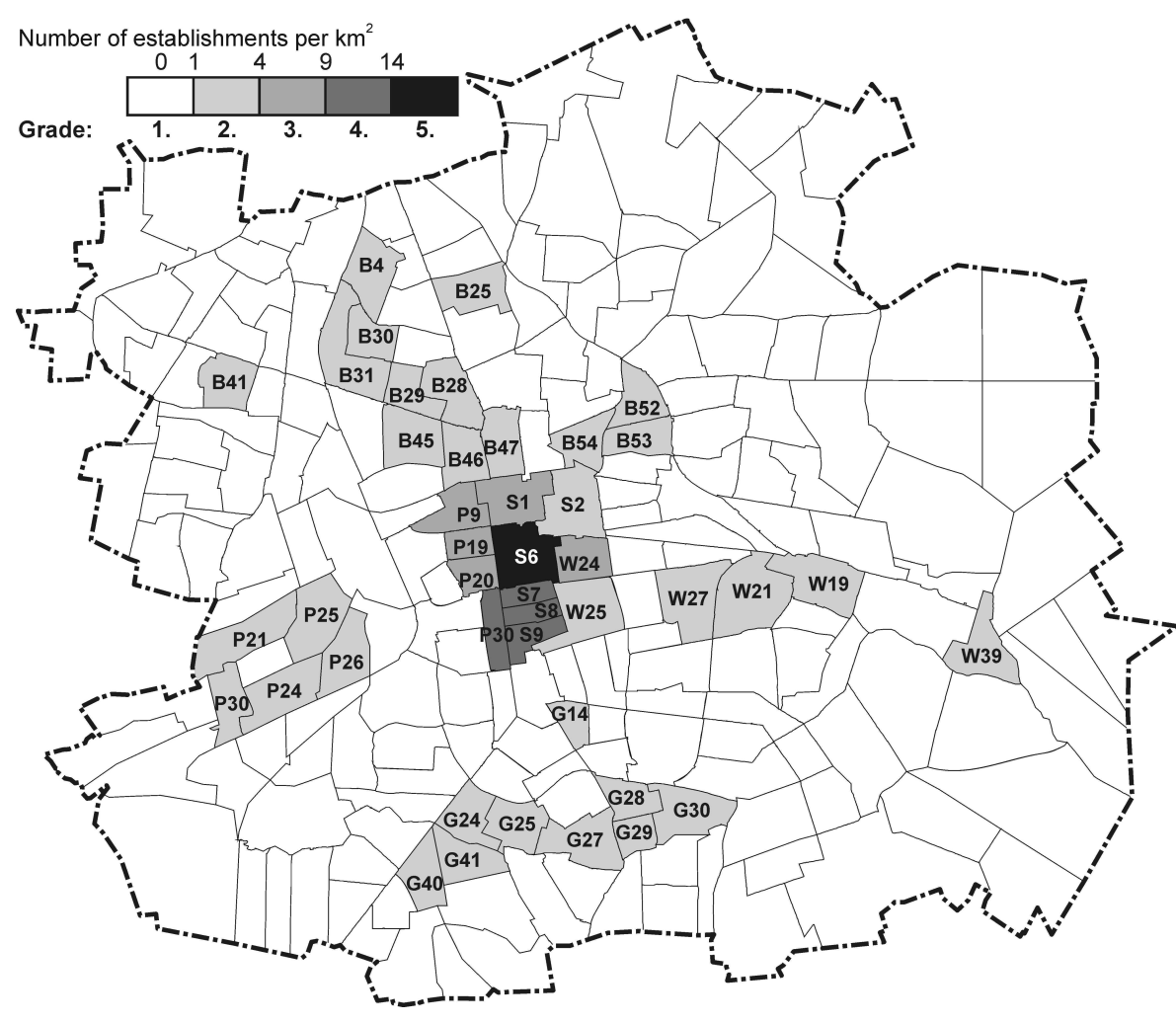

Fig. 2. Density of pubs in Łódź Source: M. MILEWSKA (2003)
St. Large concentrations are also observed at shopping centres (Manufaktura - 47, Galeria Łódzka - 19, Port Łódź - 17), around the student estates of the University of Łódź and the University of Technology, as well as by routes leading out of the city. The predominant types are bars (32\%), restaurants $(28 \%)$, pizzerias $(15 \%)$ and cafés $(10 \%)$. The number of pubs dropped dramatically (to 7\%). In 2002, there were 132 (MILEWSKA 2003), ten years later only 36 (SUŁKOWSKA 2013). A noticeable regularity is a quite even distribution of gastronomic establishments of a lower standard across the city (e.g. bars, including bars offering home-made dishes, and pizzerias), and at the same time a strong concentration of establishments of a higher standard (restaurants) in the city centre (along Piotrkowska St and in its immediate vicinity). more elegant establishments with a richer gastronomic offer increased. As a result, the structure of gastronomic facilities in Łódź changed and in 2005, there were about $620^{5}$. (KACZMAREK, LISZEWSKI \& WŁODARCZYK 2006). Despite the fact that the overall number of pubs and bars exceeded 150, restaurants and bars made up a similar percentage (about a quarter) of food facilities (Table 1).

Table 1. Łódź gastronomic facilities in 2005

\begin{tabular}{|l|c|c|}
\hline $\begin{array}{c}\text { Type } \\
\text { of establishment }\end{array}$ & $\begin{array}{c}\text { Number } \\
\text { of establishments }\end{array}$ & Percentage \\
\hline Restaurants & 151 & 24.4 \\
\hline Bars & 157 & 25.3 \\
\hline Cafes & 24 & 3.9 \\
\hline Pubs and bars & 154 & 24.8 \\
\hline Pizzerias & 54 & 8.7 \\
\hline Pastry shops & 80 & 12.9 \\
\hline Total & 620 & 100.0 \\
\hline
\end{tabular}

Source: K. SUŁKOWSKA (2013).

The latest inventory of the gastronomic facilities was made by K. SUŁKOWSKA (2013). In 2012, there were 549 in Łódź (excluding small outlets) and their distribution still shows a strong concentration (Fig. 3). Nearly half (about $47 \%$ ) can be found in the city centre (Śródmieście), with over 20\% situated on Piotrkowska
The density of gastronomic establishments varies between individual districts. Naturally, the greatest, both in absolute numbers and in the calculated coefficients, is found in Śródmieście (city centre) (Table 2, Fig. 4). In the central district of the city, there are 38 per $\mathrm{km}^{2}$ (in others - 1.39 at the most), with 275 inhabitants per establishment (in the remaining ones 7-9 times more).

In K. SUŁKOWSKA's opinion (2013), Łódź gastronomic facilities present the features of the concentric-radial model in a complex form (according to the typology by KACZOREK \& KOWALCZYK 2003). Food facilities are situated not only along the representative Piotrkowska St, but also by main roads, near transport nodes, at shopping centres and hypermarkets, around tourist attractions and at accommodation facilities. The distribution of gastronomic resources within the city space is influenced not only by its history, transportation network and the presence of tourism assets, but also the location of housing estates because in Łódź it is the residents that make up the main clientele.

Among the 550-600 Łódź gastronomic establishments, there are luxurious restaurants, all kinds of bars, pubs, thematic cafés and tea-rooms, pastry shops, fast food restaurants, etc. Apart from Polish and international (European) cuisine, restaurants serve over 30 ethnic cuisines: the most popular are Italian and French (Mediterranean), as well as Turkish and Japanese; 


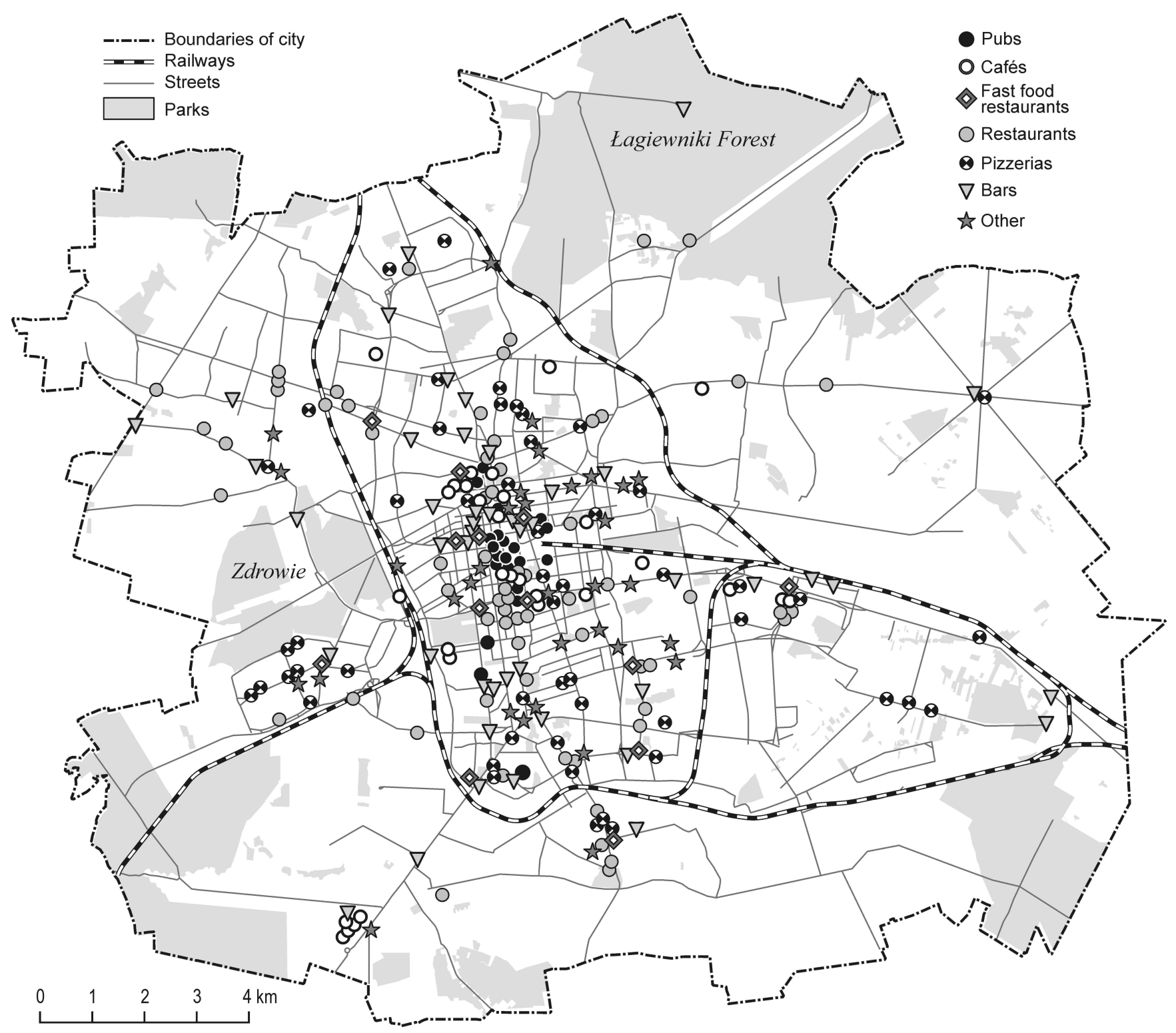

Fig. 3. Distribution of gastronomic facilities in Łódź, in 2012 Source: K. SUŁKOWSKA (2013)

Table 2. Gastronomic establishments in Łódź districts in 2012

\begin{tabular}{|l|c|c|c|c|c|c|c|}
\hline \multicolumn{1}{|c|}{ District } & $\begin{array}{c}\text { Area } \\
\left(\mathrm{km}^{2}\right)\end{array}$ & $\begin{array}{c}\text { Population } \\
\text { (thousands) }\end{array}$ & $\begin{array}{c}\text { No of } \\
\text { gastronomic } \\
\text { establishments }\end{array}$ & $\begin{array}{c}\text { Share in the total } \\
\text { number of } \\
\text { establishments } \\
(\%)\end{array}$ & $\begin{array}{c}\text { Number of } \\
\text { establish- } \\
\text { ments/ } \\
1000\end{array}$ & $\begin{array}{c}\text { No of inhabitants/ } \\
\text { gastronomic } \\
\text { establishment }\end{array}$ & $\begin{array}{c}\text { No of } \\
\text { establishments/ } \\
\mathrm{km}^{2}\end{array}$ \\
\hline Bałuty & 78.9 & 204.3 & 103 & 18.76 & 0.50 & $1,983.5$ & 1.31 \\
\hline Górna & 71.9 & 168.4 & 71 & 12.93 & 0.42 & $2,371.8$ & 0.99 \\
\hline Polesie & 46.0 & 139.1 & 64 & 11.66 & 0.46 & $2,173.4$ & 1.39 \\
\hline Śródmieście & 6.8 & 71.3 & 259 & 47.18 & 3.63 & 275.3 & 38.09 \\
\hline Widzew & 90.8 & 135.8 & 52 & 9.47 & 0.38 & $2,611.5$ & 0.57 \\
\hline Total & 294.4 & 719.0 & 549 & 100.00 & 0.76 & $1,309.7$ & 1.86 \\
\hline
\end{tabular}

Source: author based on K. SUŁKOWSKA (2013). 


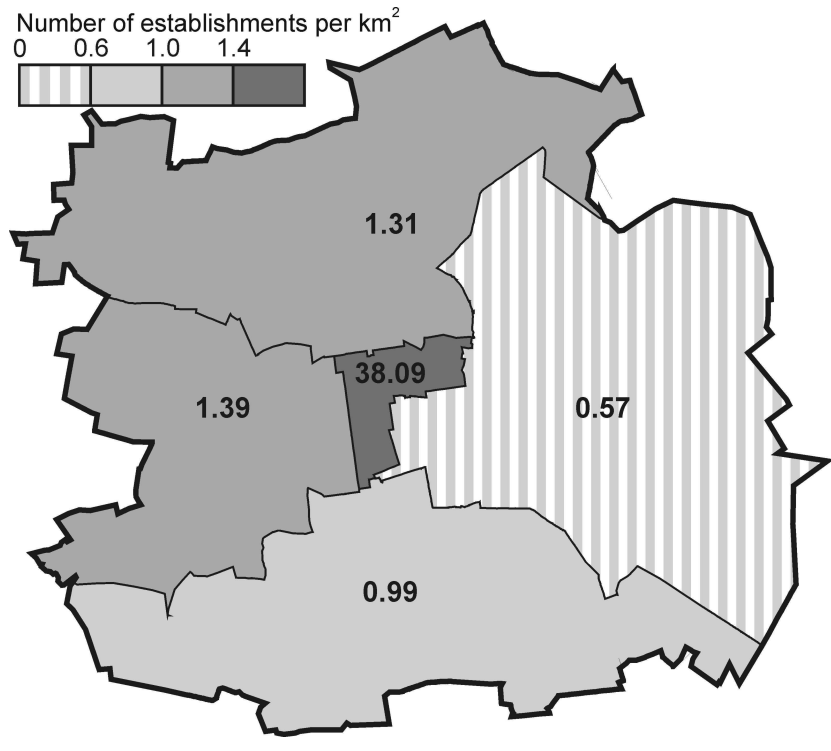

Fig. 4. The number of gastronomic establishments per $\mathrm{km}^{2}$ in the districts of Łódź, in 2012 Source: K. SUŁKOWSKA (2013)

and this reflects current trends in Polish gastronomy (DEREK 2013b). Other cuisines include those of neighbouring nations (e.g. German, Russian, Ukrainian, Czech) and Asian countries (mainly Chinese and Vietnamese). Gourmets can also try exotic dishes, e.g. Argentinian, Bulgarian, Montenegrin, Georgian, Indian, Caucasian (Armenian), Korean, Moroccan, Thai, as well as African, Arabian, Middle Eastern or Scandinavian. There are also restaurants offering fusion and molecular cuisine, so trendy today. Cuisines of the world are distributed over a small area and make up the typical gastronomic offer of a large city. Although they are not directly based on the culinary heritage of the metropolis, they may be very interesting for both inhabitants and tourists (KOWALCZYK 2014).

Another characteristic feature of Łódź gastronomy since the end of the $20^{\text {th }}$ c., is to locate gastronomic establishments in revitalized buildings of postindustrial heritage, due to the large number of former textile factories available (also situated in the very centre of the city). Thanks to low rents, spaciousness, various opportunities for designing the interiors, a characteristic industrial atmosphere as well as a fashion for revitalization, in recent years many gastronomic and entertainment establishments have been opened in former Łódź factories.

I. PIETRUSZKA (2015) made an inventory of 12 factory complexes in Łódź with a gastronomic function. They were mostly single establishments but four however include a larger number: Manufaktura, Off Piotrkowska zone, Piotrkowska 217, and Księży Młyn situated outside the city centre (Fig. 5). Each of these complexes has different origins, a different administrator and a different character.
Manufaktura is the largest shopping, service and entertainment centre in Poland ${ }^{6}$. It was created in 2006, on the premises of the revitalized Poznański factory complex. From the very beginning, the French investor (Apsys) assumed that the 'new market square of Łódz' would be surrounded by over 20 restaurants serving dishes from all over the world, as well as cafés and pubs (STASIAK 2005, KOSTECKA 2007). The buildings of the former weaving and finishing plants accommodated some famous (not only chain) restaurants, such as the French restaurant $L^{\prime} E c r u$, considered to be the most expensive in Poland (open 2007-11). Despite the constantly changing chains, in the Manufaktura square there are always places offering various cuisines of different standards and prices (in $2015-28$ restaurants). Added to this are fast service bars in the shopping centre, Andel's Hotel restaurant and bar, as well as the café at the Museum of Art $m s^{2}$.

The Off Piotrkowska zone was created on the premises of a degraded factory complex called China Town $^{7}$. The neglected area was taken over by OPG (Orange Property Group). After basic repairs had been made, a unique project started involving the creation of an alternative culture, and an art and creative business centre. Unadorned, post-industrial interiors were rented by fashion designers and artists as their ateliers. They were also used as exhibition areas, rehearsal halls, showrooms, concept stores, as well as music clubs, restaurants and club-cafes. OFF Piotrkowska soon became a favourite meeting place for young people in Łódź, and in 2014 it won the 'Seven Wonders of Poland' competition announced by National Geographic Traveler. The avant-garde ambience was compared to the atmosphere of New York or Berlin. Off Piotrkowska comprises over 20 restaurants, bars and pubs (with seasonal outdoor terraces), located around a spacious square. They are highly original places, with unique ideas for business, décor, cuisine, a combination of cultural and commercial functions, and offering a wide range of events. However, the standard of services is medium or low.

217 Piotrkowska St - has recently become a trendy address in Łódź associated with gastronomy. In the $19^{\text {th }} \mathrm{c}$., it was the largest metallurgic factory in the region owned by a German emigrant from Bohemia, Joseph John. Currently, it is administered by a Warsaw development company, OKAM Capital, which has organized a centre for young, creative people. It consists of artists' ateliers, offices, shops and gastronomic establishments. The area is a venue of unique cultural and entertainment events, such as Łódź Street Food Festival.

Księży Młyn (an industrial settlement which belonged to the Łódź king of cotton, Karol Scheibler) differs from the others in that it is situated away from 


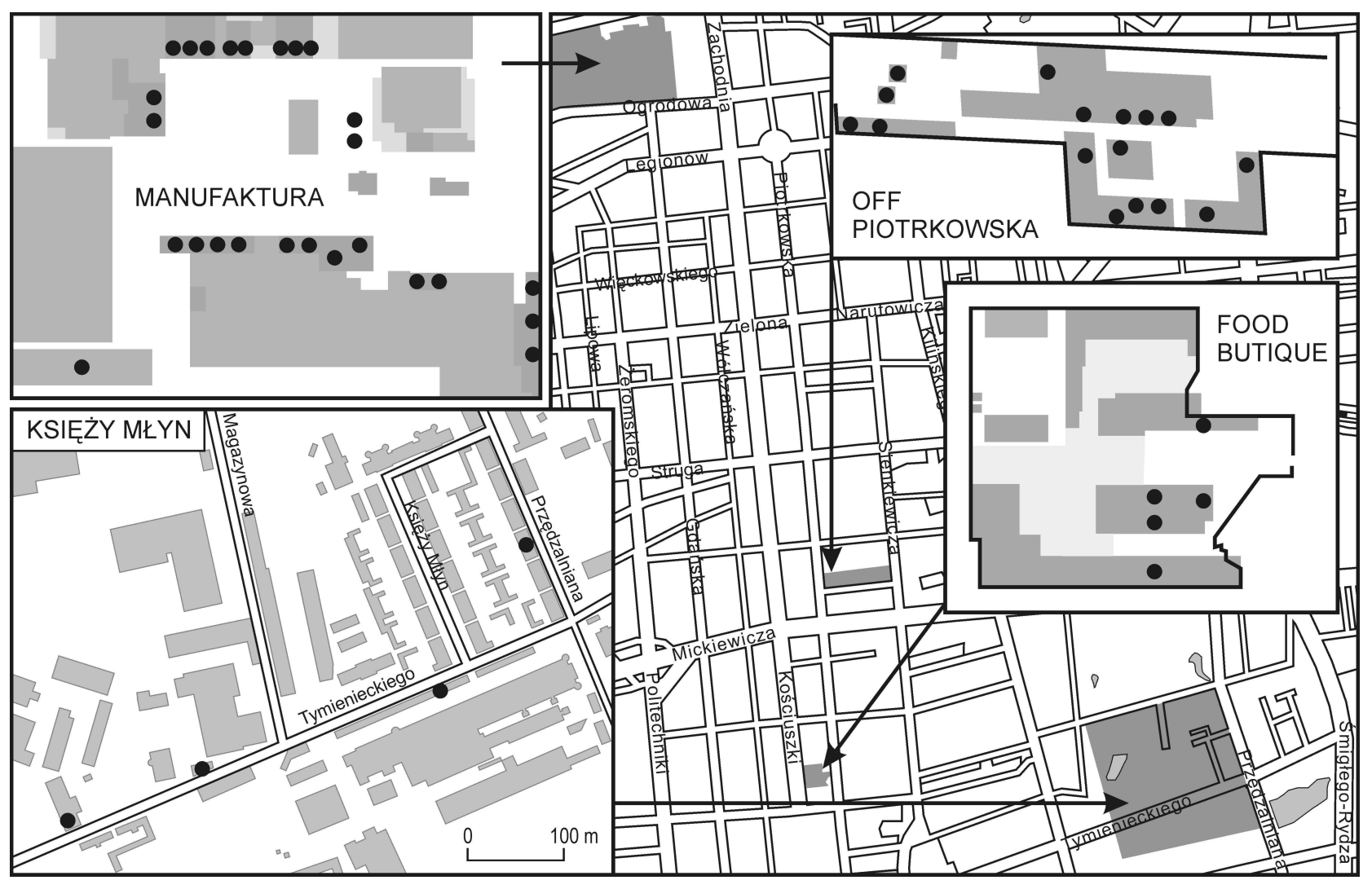

Gastronomic establishments

Fig. 5. Gastronomic establishments in revitalized post-industrial complexes in Łódź Source: author

Piotrkowska St, the gastronomic establishments cover a larger area and are more dispersed. The district is not governed by one administrative body, which is why the appearance of gastronomic services in this area is an uncoordinated and long-lasting process. Apart from the oldest restaurant - U Szwajcara - at the former factory gatehouse, there are other establishments, for instance Gronowalski \& Buddha Pub (the property of a textile, jewellery and design company). For several years, the revitalization of the workers' housing estate has been undertaken by the city council which lets renovated spaces to artists as studios. One of them accommodated a café (Kreatoora).

Interesting conclusions regarding the perception and evaluation of Łódź gastronomic establishments in the revitalized post-industrial facilities are provided by the research by I. PIETRUSZKA (2015) ${ }^{8}$. The most important factor determining the choice of a restaurant turned out to be friends' recommendation (43.2\%), followed by post-industrial location $(25.6 \%)$ and the ambience $(12 \%)$. The influence of industrial architecture on the decision to visit a given place was described as strong or very strong (jointly, over $43 \%$ of answers). This aspect was not taken into consideration by only $16.4 \%$ of the respondents.
For most respondents it is important that the architecture of a building as well as the design of the interiors somehow refers to the history and industrial character of the city. Therefore, a frequently mentioned drawback was insufficient relation between the décor of interiors and their post-industrial architecture, as well as the very small number of 'Eódź' dishes on the menu. This opinion was shared by both the inhabitants of Łódź (62\% of the respondents) and visitors from Łódź wojezództwo (10.8\%) and further regions (e.g. Warsaw, Płock, Kraków, Wrocław, Nowy Targ and Olsztyn).

The functional-spatial changes in the centre of Łódź correspond to the conception of the creation of a district of gastronomic services. A. KOWALCZYK (2014) differentiated four stages of this process: I - street food, II - food street, III - food street + food court, IV - food district. Łódź should be placed between stages III and IV (a step before or perhaps even at the beginning of the forming of a food district). At present, apart from the old food street (Piotrkowska St), new food courts (post-industrial complexes) are appearing and developing, and the concentration of gastronomic services within the city space is steadily increasing. It must be remembered, however, that reality is more compli- 
cated than the theoretical model. The vicinity of Piotrkowska St has already had the function of a gastronomic and entertainment centre (the era of pubs in the early $21^{\text {st }} \mathrm{c}$.). On the other hand, the latest gastronomic trends generate a growing demand for street food; hence the growing popularity of food trucks in Łódź. In the circumstances, we should rather speak of a renaissance of the central gastronomic district. This phenomenon certainly requires further study and analysis.

\section{GASTRONOMIC EVENTS}

Tourists fond of the art of cooking are most interested in different kinds of gastronomic events ${ }^{9}$ such as food festivals, days of particular regional dishes and products, religious and folklore holidays related to gastronomy, cooking competitions and tournaments, food fairs, cooking workshops, and meetings with 'gastronomy people' (STASIAK 2015).

The trend of turning cookery into events is also found in Łódź. In the opinion of A. KOZŁOWSKA (2015), this reflects broader trends and transformations that are taking place in the awareness of society as regards lifestyle, ways of spending free time, ecology, healthy eating, and the fashion for cooking created by the media. Łódź as a large city with well-developed gastronomic resources offers a wide range of foodrelated events. The most important ones mentioned by A. KOZŁOWSKA (2015) include:

Festiwal Dobrego Smaku ('Good Taste Festival') the oldest, largest and best known gastronomic event in Łódźc ${ }^{10}$. Initially, it consisted only of culinary shows, but in 2010 the festival took the form of a competition among restaurants and cafés which have to prepare one dish with reference to the motto of the event (2012 - Z tradycja i sezonowo (Traditional and seasonal); 2013 - Kulinarnie nakręceni (Culinarily Stoked) - a merger of film and cooking; 2014 - Zapomniane, na nowo odkryte (Forgotten, rediscovered). Chefs' creations are assessed by both the audience and a professional jury.

Festiwal Kawy (Coffee Festival) - a competition addressed to people dealing with coffee professionally and as a hobby. Coffee fans visit cafés, which sell espresso and cappuccino for a considerably lowered price throughout the weekend. The customers choose the best café and the jury - the best coffee.

Eódź Street Food Festival is a reflection of the latest trends in urban gastronomy: the fashion for street food and food trucks (vehicles with equipment for preparing food). The event attracts food trucks from all over Poland, restaurants from Łódź and amateur cooks who do not own any gastronomic establishments. The audience is served dishes from all over the world and the offer changes from event to event ${ }^{11}$. The customers may buy food to go, most of them, however, have their meals on the premises of the 217 Piotrkowska St factory complex. Despite the very modest conditions in which the event is organized, the number of customers is on the rise, up to 12000 in a single day.

Eko Targ (Eco Market) - takes place every Saturday in the OFF Piotrkowska zone (in summer - on the car park, in winter - inside the shopping gallery). Carefully selected exhibitors invited to take part in the event sell products from all over the world, but above all those which are of high quality, organic, not mass produced, with aesthetic and original wrappings. The goods offered change, depending on the season and the type of firms which want to participate.

Restaurant Day - a world eating festival initiated in 2011 in Finland. A year later the festival was held in Poland for the first time. It involves amateur cooks running their dream restaurant at a freely selected place (their own house, a museum, a park, etc.). It is never known how many and what kind of restaurants will be opened during the next event. In Łódź, there could be none to several one-day establishments. For instance, on $15^{\text {th }}$ February 2015, at the Museum of Cinematography, a restaurant called Zjadliwości was open for 6 hours, serving only white dishes. It was visited by about 100 people (KOZŁOWSKA 2015).

Międzynarodowe Targi Żywności Ekologicznej $i$ Regionalnej (International Fair of Ecological and Regional Food) - the largest in Poland (over 300 exhibitors) devoted to ecological food. It is organized under the honorary patronage of the Ministry of Agriculture and Rural Development. The leading idea is the promotion of the culinary heritage of Polish regions, their traditional products, as well as local food companies. The fairs offer the opportunity to taste and buy many ecological products.

Mixer Regionalny - an event aimed at integrating the inhabitants of Łódź province (wojewodztwo) and presenting the achievements of individual local government areas. However, culinary elements play an important role in the promotion of gminas and powiats. Tasting and selling gastronomic products is organized by Koła Gospodyń Wiejskich (village clubs - literally: 'farmers' wives') as well as local entrepreneurs from the food sector, using the stalls situated in Stary Rynek (Old Market Square) and Piotrkowska St.

Detailed data regarding gastronomic events held in Łódź in 2014 is presented on Table 3. We may add here the International Tourism Fairs entitled 'On the borderline between cultures' (Na styku kultur), whose important part is the regional products fair. Let us also mention the regularly held, though usually small, cooking workshops which are organized every week- 


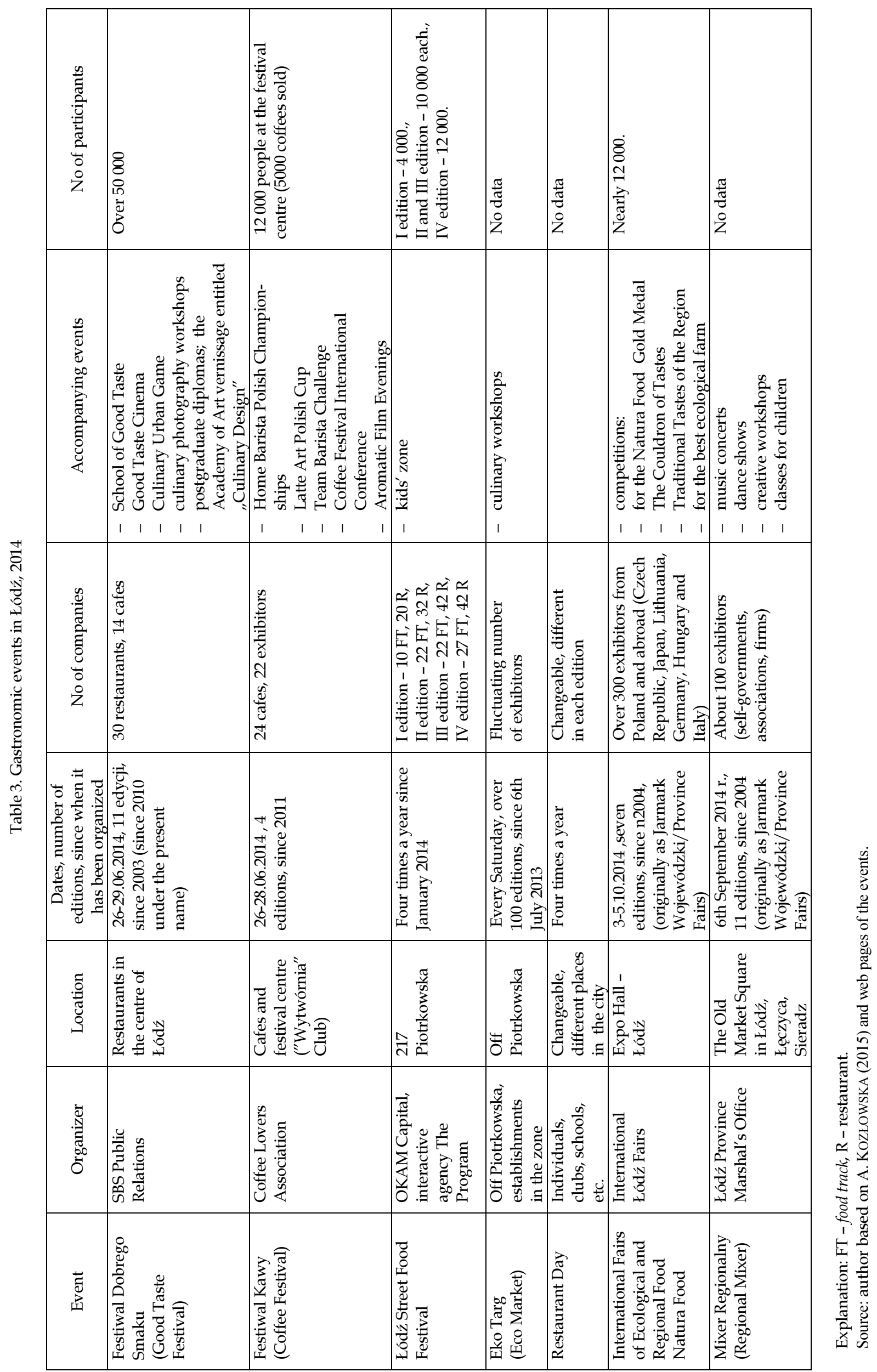


end by selected restaurants (e.g. in the Off Piotrkowska zone). They enable the participants to taste the specialities of a given cuisine, cook with renowned chefs, bloggers or celebrities, or even discover the secrets of culinary photography.

The research conducted by A. KOZŁOWSKA (2015) shows that Łódź culinary events were attended mostly by inhabitants of Łódź (84\%) and neighbouring powiats (Łódź East, Pabianice, Zgierz). Occasionally, visitors from more distant cities appeared (BuskoZdrój, Poznań, Kraków, Warsaw). The participants were mostly women $(75 \%)$, university graduates (63\%), aged 26-55 (54\%), describing their financial situation as average (51\%) or good $(40 \%)$, and professionally unconnected with the gastronomic industry (70\%). The majority of the 202 respondents took part in the Festiwalu Dobrego Smaku (68\%) and Eódź Street Food Festival (58\%). The most frequent motivation was the wish to discover new tastes and visit new establishments, as well as curiosity (50\% of all answers). The participants of the events are active consumers. Only $9 \%$ did not buy any food products, the others bought dishes to eat on the spot (44\%), take-away products, bread, vegetables, beverages, dried fruit and nuts, and even cosmetics.

Culinary events were highly evaluated by the respondents (on a scale from 1 to 6). Only Mixer Regionalny was rated below 4, while all the other events crossed this threshold (Festiwalu Dobrego Smaku - 4.8, Łódź Street Food Festival - 4.6; Festiwal Kawy - 4.4). The main advantages of the events included an original offer (unique tastes, new culinary experience, the participation of many establishments, equal prices for individual dishes), effective organization (including promotion of new places) and exceptional atmosphere (an interesting way to spend one's free time, good fun, amiable people, integration of participants). Some disadvantages were also pointed out, e.g. small choice of dishes, high prices, poor promotion, as well as... the fact that the events were organized too rarely, too many participants, queues and lack of festival dishes at the end of the day.

\section{OTHER ELEMENTS OF ŁÓDŹ’S GASTRONOMIC POTENTIAL}

The most important components of the gastronomic potential of Łódź include the rich and varied gastronomic resources as well as the original culinary events, described above. However, it is possible to enumerate some other elements which make the city attractive to lovers of good cuisine.

Łódź Convivium is one of nine Polish branches of the Slow Food International Association. This is a famous movement defending the 'right to taste'. Eódź Convivium is based at 97 Piotrkowska Club, and its chairman is a renowned Łódź restaurant owner, Grzegorz Zieliński. The branch has been organizing culinary meetings with famous people (chefs, taste promoters, etc.), thematic suppers, food product fairs, for ten years.

The museum workshop entitled 'In the dining room and in the pantry' - although Łódź does not have a typical museum of gastronomy, at the Museum of Industrial Interiors - Księży Mtyn Residence - an educational project is run which enables students to discover the history of Łódź cuisine. The workshops include a presentation of furniture typical of the dining room and the pantry, as well as home customs and traditions in Łódź at the turn of the $20^{\text {th }} \mathrm{c}$. The classes are interactive: children practice table manners, guess what cutlery items and individual kitchenware were used for, they lay an enormous table in the ball room and prepare a menu based on a $19^{\text {th }} \mathrm{c}$. cookery book.

Celebrity cooks - in recent years, culinary TV shows $^{12}$ in Poland have been steadily gaining in popularity. The most popular are watched by over three million viewers, and the hosts, judges and contestants become real celebrities. Chefs from Łódź appear in many programs. One of them is Liliana Filipiak - a participant in the first edition of Top Chef (Poland) in 2013 and the owner of the Lili restaurant (OFF Piotrkowska). In 2015, the winner of the $4^{\text {th }}$ Polish edition of Hell's Kitchen was Damian Marchlewicz from Łódź. In Manufaktura there is a restaurant Polka, endorsed by Magda Gessler, and another Galicja, supported by Robert Makłowicz.

Post-graduate studies - Food Design (Projektowanie Kulinariów) - opened in 2013, at the Faculty of Fabrics and Clothing, the Academy of Art in Łódź, they were the first Polish post-graduate studies devoted to gastronomy as an art. Classes based on the workshop and design system are conducted not only by Academy teachers, but also by famous Łódź and Warsaw restaurant owners, chefs, culinary journalists and critics. The course finishes with a diploma presented at the Festiwal Dobrego Smaku. So far, since it was opened only three years ago, the course has been chosen by about 50 students from all over Poland.

\section{CONCLUSIONS}

The analysis of the development and current state of Łódź gastronomy presented allows us to draw some general conclusions.

1. Łódź possesses vast gastronomic resources, as well developed as in other large Polish cities (KACZ- 
MAREK, LISZEWSKI \& WŁODARCZYK 2006), due to the wide range, high standard and diversified character of gastronomic establishments, as well as the high standard of service.

2. The exceptionality of Łódź gastronomy is based, for instance, on breaking the continuity of culinary traditions. In the course of history, the city lost its Russian, German and Jewish populations and their original cuisines disappeared. Since the end of the $20^{\text {th }}$ c., due to the growing interest in the multicultural history of Łódź, attempts have been made to recreate the cuisines of the four peoples (Analogia and $U$ Kretschmera restaurants) or individual nations (the Jewish Anatewka restaurant), or Łódź interwar cuisine (Ślepy Maks ${ }^{13}$ ). Because of the lack of typical local specialities, attempts are being made to create Łódź dishes based on historical recipes and names of dishes referring to the film heritage of the city or current events.

3. The gastronomic resources of Łódź have 'always' been concentrated on Piotrkowska St and nearby. It is a natural gastronomic and entertainment zone. In the last 25 years it has gone through periods of prosperity and regression, changing its character considerably. After the decline of gastronomy in the early 1990s, the end of the $20^{\text {th }} \mathrm{c}$. brought a dynamic development of pubs. Establishments with a limited gastronomic offer but with a rich cultural and entertainment programme attracted crowds of people, both inhabitants and visitors. At the beginning of the $21^{\text {st }}$ c., their popularity started to decrease and Piotrkowska St lost its clubbing character. A remedy for this decline is the second complete renovation of the street, finished in 2014. The renewed promenade is called the 'drawing room' of Łódź, and gastronomy shows the first signs of recovery.

4. A new impulse to the development of gastronomy in Łódź is woonerfs ${ }^{14}$, and above all creating food courts in former factory complexes (Manufaktura, Off Piotrkowska, 217 Piotrkowska, Księży Młyn). Although they differ in size or origin, they all lead to a concentration of a variety of gastronomic establishments on a relatively small area. This brings specific economies of scale (increased power of attraction, complementary supply, cooperation during events), as well as creating a unique gastronomic space of an unusual character. It is typical of Łódź to set up gastronomic establishments in post-industrial buildings (though frequently the interior design and menu do not refer to the industrial history of the city), which creates a particular, avant-garde atmosphere. Piotrkowska St and the nearby complexes can be regarded as a food district (KOWALCZYK 2014), a culinary attribute and a visiting card for the city.

5. We must also point out the constantly growing standard of gastronomic services which is proved by the fact that Łódź restaurants are present in the Polish edition of the prestigious culinary guide, Gault \& Millau $^{15}$, or the successes of Łódź inhabitants on popular culinary TV shows. It was in Łódź where the first Sfinks opened (1995), which in 20 years developed into the largest chain of casual dining restaurants in Poland (nearly 100 establishments). Łódź gastronomy adopts the latest culinary trends rapidly and creatively. Several years ago, there came a fashion for bars serving vodka and snacks; they were followed by club cafés. Currently, we are going through 'burgermania' (fashion for eating dietetic, vegetarian burgers). Ethnic restaurants (e.g. sushi bars) are very trendy, and those offering fusion, molecular, tex-mex and slow food, as well as eco-food and traditional product shops.

6. A reflection of broader trends is the organization of various culinary events. Although they are mostly regional, they have considerable potential and in the future they may become large events attracting fans of good food from all over the country.

7. The large variety of gastronomic establishments, the high standard of services and reasonable prices of meals can make Łódź very attractive for foodies, both tourists and inhabitants. The characteristic feature of Łódź gastronomy is the combination of industrial atmosphere, modern design and the original ideas of the owners, as well as the unique, unpretentious atmosphere, which is often stressed by customers. For now, Łódź does not make full use of its culinary heritage, neither for promotion not for creating the tourism product of the city. These elements may, however, soon become separate products (buildings or events), or components of a broader tourism product for the area. In the second case, food would be an important part of products connected with the industrial tourism brand, or even film heritage (cf. 'Industrial strongholds of the 19th c.' and Hollytódz, STASIAK 2007). It is hard to expect that a gastronomic museum could be established in Łódź or that old culinary traditions (local products) might be revived. However, it seems quite possible that a product called 'Cuisines of the world in Piotrkowska St' will soon appear, e.g. in the form of an urban culinary trail across the already existing ethnic restaurants. This would require active cooperation of the managers of gastronomic establishments and tourism organizers. A real challenge, however, would be to create an exceptional, unique offer of culinary tourism, based on historical multiculturality and post-industrial ambience.

\section{FOOTNOTES}

1 A. STASIAK (2015) distinguishes between three necessary components of culinary tourism: high quality food, cognition and experience

2 Łódź's population increased 600 times: from less than a thousand in 1815 to 600000 in 1915. 
3 'A dive, a shot and a snack' ('meta, seta, galareta') became the basis of the alcohol and a snack cheap bar format, based on nostalgia for socialist times in Poland. The bars gained considerable popularity all over Poland at the beginning of the $21^{\text {st }} \mathrm{c}$.

${ }^{4}$ As of 1st November 2015 (www.minrol.gov.pl).

${ }^{5}$ Excluding small gastronomy outlets.

${ }^{6}$ The overall area: 27 hectares; GLA (gross leasable area): $110000 \mathrm{~m}^{2}$.

7 The name comes from stands serving oriental cuisine, which in fact is mainly Vietnamese, not Chinese.

8 A survey conducted in 2014 among 250 customers of gastronomic establishments (Galicja and Tawerna Pepe Verde restaurants in Manufaktura, traveller's café, Daleko Blisko, in OFF Piotrkowska zone, Gęsi Puch restaurant (17 Stefanowskiego St) and the artistic café, Kreatoora, in Księży Mtyn.

${ }^{9}$ It was stated by $79 \%$ of UNWTO members participating in a survey (Global Report on Food Tourism) (2012); culinary trails as well as culinary courses and workshops came second with $62 \%$ each.

10 The popularity of the Good Taste Festival is proved by both the attendance (50000 in 2014) and sales in individual establishments (e.g. the Lokal restaurant sold 600 meals during only 6 hours, while Ato Sushi - over 1500 meals during the whole event).

11 The fourth in 2014 featured American, Ethiopian, Spanish and Italian dishes.

12 The can be divided into programmes of the following types: cooking in the TV studio, culinary travels and reality show in the kitchen (STASIAK 2015).

13 The name of the establishment comes from the nickname of Menachem Bomsztajn - a legendary Łódź gangster operating in the Bałuty district known as the king of revenge.

14 Woonerf (Dutch 'a street to live in'): an urban courtyard, public space, which combines the functions of a street, promenade, car parking and meeting place (https://pl.wikipedia org/wiki/Woonerf ). The woonerfs in Łódź are in two streets perpendicular to Piotrkowska St (6 Sierpnia and Traugutta Sts); the next four are being planned.

${ }^{15}$ So far, the best known guide, Michelin, has evaluated only restaurants in Warsaw and Kraków. In 2014, the first Polish guide, Gault \& Millau, included seven establishments, and a year later - nine. The Delight in Andel's Hotel was chosen as the best restaurant (two chef's toques).

Translated by Ewa Mossakowska

\section{BIBLIOGRAPHY}

CUDNY W., 2002, Imprezy kulturalno-rozrywkowe na ul. Piotrkowskiej w opinii przechodniów i mieszkańców, Turystyka $i$ Hotelarstwo, 1, pp. 111-126.

DEREK M. (ed.), 2013a, Turystyka kulinarna, Prace i Studia Geograficzne, 52, $154 \mathrm{pp}$.

DEREK M., 2013b, Kierunki rozwoju usług gastronomicznych w warszawskiej dzielnicy Śródmieście, Prace i Studia Geograficzne, title: Turystyka kulinarna, M. Derek (ed.), 52, pp. 85-100.

Gault \& Millau. Polska. Żótty przewodnik 2016, 2015, Gault \& Millau.

JASKULSKI M., 2012, Piwo, flaki garnuszkowe, petersburskie bliny i kawior astrachański, czyli z dziejów gastronomii łódzkiej do 1918 roku, Dom Wydawniczy Księży Młyn, Łódź, 226 pp.

KACZMAREK J., LISZEWSKI S., WŁODARCZYK B., 2006, Strategia rozwoju turystyki w Łodzi, Łódzkie Towarzystwo Naukowe, Łódź, 129 pp.
KACZOREK A., KOWALCZYK A., 2003, Modele lokalizacji usług gastronomicznych na obszarach miejskich, Prace i Studia Geograficzne, 32, pp. 191-203.

KLIMA E., BRATKOWSKI J., 2005, Usługi gastronomiczne, [in:] J. Dzieciuchowicz (ed.), Ustugi rynkowe w Łodzi w dobie transformacji, Wyd. Uniwersytetu Łódzkiego, Łódź, pp. 147-183.

KOSTECKA J., 2007, Manufaktura - nowa przestrzeń turystycznorekreacyjna Łodzi, Turystyka i Hotelarstwo, 12, pp. 9-36.

KOZŁOWSKA A., 2015, Wybrane wydarzenia gastronomiczne w Łodzi jako efekt trendów europejskich, [in:] B. Krakowiak, A. Stasiak (eds.), Kultura i turystyka - wokót wspólnego stotu, Regionalna Organizacja Turystyczna Województwa Łódzkiego, Łódź, pp. 333-356.

KRAKOWIAK B., STASIAK A. (eds.), 2015, Kultura i turystyka wokót wspólnego stotu, Łódź, 376 pp.

KRZYWIK KAŹMIERCZYK J., 2014, Lorneta z meduza, Dom Wydawniczy Księży Młyn, Łódź, 216 pp.

MiLEWSKA M., 2003, Łódzkie puby jako atrakcja turystyczna miasta $\mathrm{w}$ opinii przechodniów i osób przyjeżdżających do Łodzi, Turystyka i Hotelarstwo, 3, pp. 101-117.

MiLEWSKA M., PRĄCZKO A., STASIAK A., 2010, Podstawy gastronomii, PWE, Warszawa, $364 \mathrm{pp}$.

MiLEWSKA M., WŁODARCZYK B., 2004, Historia hotelarstwa w Łodzi, Turystyka i Hotelarstwo, 5, pp. 55-93.

NALEWAJKO J., 2006, Rozwój, funkcjonowanie i miejsce usług gastronomicznych w przestrzeni Łodzi, [in:] T. Marszał (ed.), Łódź - wybrane zagadnienia zagospodarowania przestrzennego, Wyd. Uniwersytetu Łódzkiego, Łódź, pp. 159-178.

PIETRUSZKA I., 2015, Adaptacja wybranych łódzkich obiektów poprzemysłowych na potrzeby świadczenia usług gastronomicznych, [in:] B. Krakowiak, A. Stasiak (eds.), Kultura i turystyka - wokót wspólnego stotu, Regionalna Organizacja Turystyczna Województwa Łódzkiego, Łódź, pp. 357-376.

STASIAK A., 2005, Centrum handlowo-rozrywkowe Manufaktura jako nowa atrakcja turystyczna Łodzi, [in:] Dziedzictwo przemystowe jako atrakcyjny produkt dla turystyki i rekreacji. Doświadczenia krajowe i zagraniczne, II Konferencja Międzynarodowa, Zabrze, 12-13.05.2005 r., GWSH im. W. Korfantego, UM w Zabrzu, Katowice, pp. 215-220.

STASIAK A., 2007, Gastronomia jako produkt turystyczny, Turystyka $i$ Hotelarstwo, 11, pp. 103-129.

STASIAK A., 2015, Rozwój turystyki kulinarnej w Polsce, [in:] B. Krakowiak, A. Stasiak (eds.), Kultura i turystyka - wokót wspólnego stotu, Regionalna Organizacja Turystyczna Województwa Łódzkiego, Łódź, pp. 119-150.

SUŁKOWSKA K., 2013, Baza gastronomiczna jako potencjalny produkt turystyczny Łodzi, master's thesis, promoter S. Liszewski, Institute of Urban Geography and Tourism UŁ, Łódź.

WOJCIECHOWSKA A., 2014, Fifka $i$ żulik, czyli domowa kuchnia tódzka, Centrum Inicjatyw na Rzecz Rozwoju „Regio", Łódź, 120 pp.

ZARĘBSKA A., BOROWSKA I., 2015, Łódzka kuchnia czterech kultur The Lodz Cuisine of Four Cultures, Dom Wydawniczy Księży Młyn, Łódź, 96 pp.

http:/ / ekotarg-lodz.pl.

http:/ / festiwaldobregosmaku.eu.

https://pl.wikipedia.org/wiki/Woonerf.

www.milosnicykawy.pl.

www.minrol.gov.pl/pol/Jakosc-zywnosci/Produkty-

regionalne-i-tradycyjne/Lista-produktow-tradycyjnych.

www.restaurantday.org/pl.

www.targi.lodz.pl.

Article received:

10 November 2015 